\title{
Readiness in Mathematics Flipped Classroom of Filipino Secondary School Teachers
}

\author{
Mary Jo-ann A. Juarez ${ }^{1}$, Nora V. Marasigan ${ }^{1}$, Shaira Anne P. Natanauan ${ }^{1} \&$ Gemmalyn M. Trinidad $^{1}$ \\ ${ }^{1}$ College of Teacher Education, Batangas State University JPLPC-Malvar, Batangas, Philippines \\ Correspondence: Nora V. Marasigan, College of Teacher Education, Batangas State University JPLPC-Malvar, \\ Batangas Province, 4232, Philippines.
}

Received: October 19, 2018; Accepted: November 17, 2018; Published: January 3, 2019

\begin{abstract}
School's access to technology is increasing steadily every day and most of these technologies are now even used in classroom. Due to these circumstances, educators' ideas of using technology to support deeper learning in multiple ways gave rise to the concepts of distance and blended learning. Hence, this study determined the readiness in Mathematics flipped classroom of selected Filipino secondary school teachers at the Division Schools of Tanauan City during the School Year 2016-2017. Specifically, it dealt with the following: profile of the respondents in terms of sex, age, highest educational attainment, and number of seminars attended related to ICT; respondents' assessment on their readiness in Mathematics flipped classroom; and relationship between the respondents' profile and their readiness in Mathematics flipped classroom.

By employing the descriptive type of research with the researcher-made questionnaire, the study found out that the respondents were ready in Mathematics flipped classroom. Moreover, the results of the study revealed that there was a significant relationship between the respondents' profile and their readiness in Mathematics flipped classroom. With these, the researchers proposed a course of action to support the readiness of Mathematics teachers in a flipped classroom.
\end{abstract}

Keywords: mathematics flipped classroom, flexible environment, learning culture, intentional content, professional educator

\section{Introduction}

Learning is the acquisition of knowledge and information in various ways. Most people perceived learning as interactions that take place inside the school while some see it as realizations gained through prior experiences. In today's fast-changing world, technology has big contribution to education and learning. Many technological advances offer new knowledge and resources in schools worldwide; thus, enriching curricula and altering the types of teaching available in the classroom. Schools' access to technology is increasing steadily every day and most of these technologies are now used in classroom. Due to these circumstances, educators used technology in ways that can benefit not just the teacher but also the learners. Educators' ideas of using technology to support deeper learning in multiple ways gave rise to the concepts of distance and blended learning.

Distance learning, sometimes called e-learning, is a formalized teaching and learning system specifically designed to be carried out remotely by using electronic communication. Horn \& Staker (2012) define blended learning as a formal education program with face-to-face instruction, in which a student learns at least in part through online delivery of content and instruction. Indeed, distance and blended learning have distinct features with similarities on online usage and differences on the manner of delivery.

Studies suggested the use of another learning approach which is the flipped learning. Similar to the concepts of distance and blended learning, this approach makes use of technology as a teaching tool. Some notable educators have been comparing the three learning approaches in terms of their screen cast or video components, but there are still clear differences. Distance learning occurs remotely, and teachers do not engage in face-to-face interactions. Virtual class meetings, assignments, and lectures happen online through a course management website. Meanwhile, blended classes also have an online element, but that usually occurs during class time along with direct student-teacher contact.

Students' experiences in face-to-face sessions vary; however, they are not necessarily different from what occurs in a traditional classroom. In the flipped classroom, the use of videos or other digital technologies to deliver content 
outside of class does not guarantee that anything different will occur during class time. Yet, due to the emphasis on students becoming the agents of their own learning rather than the object of instruction, the flipped learning model can enable educators to make the shift from teacher-driven instruction to student-centered learning.

The flipped classroom approach is embedded in socio-constructivist concepts of education and active learning, and embraces and values informative media used for content delivery. The flipped classroom method has developed from key educators and scholars who have founded their flipped classes on concepts and ideas of active learning, blended education, differentiated instruction, and communal inclusion, pursuing to synthesize these concepts in the flipped classroom approach (Hamdan et al., 2013).

Bergmann and Sams (2012) have taught flipped high school science classes since 2009, and also are considered the originators of the modern flipped class model. They have recently published a book, which has been considered a strong instruction resource by the Flipped Learning Network. They also found that a strong point of the flipped classroom model is through its flexibility, which permits educators to tailor their core curriculum and to employ more time speaking to their learners and differentiating instruction. Currently, the flipped classroom method continues to advance as educators implement and adapt this approach to their instructional needs.

Furthermore, Overmyer (2012) described flipped classroom as a teaching approach that reverses the role of the schoolroom instruction and out-of-school homework. Learners are provided instructional resources before class which commonly includes a video discourse which the teacher prepared in advance.

A flipped class combines two well-known elements of education: the lecture and active learning. Learners have access to video lectures beforehand along with other related material, which frees up additional face-to-face time to let students search for clarification from educators, work together with peers, and practice relating concepts while getting supervision and feedback right from experts. Educators who flip their class value lectures given as homework, as support to learning. Homework is essential because it is a time where learners can share their learning improvement with their family, be only with their thoughts, reflect on their education, and assess the material as well as the educator's feedback (Fulton, 2012).

Nowadays, most teachers tend to focus on a normal traditional lecture wherein time is allotted on discussing the lesson to students then proceeding to giving activities. Teachers usually make this as a routine causing the students to fail in appreciating the subject matter itself. Through engaging students on flipped classroom, the teacher will catch the attention of students in a way that the students will also be motivated to learn.

With the K-12 curriculum which promotes technical and vocational growth among students and the flipped classroom approach which uses technology as tool, the approach can be incorporated to enhance and deliver a more positive change in teaching and education. The Philippines is now facing the age of globalization where technology breakthroughs are advancing. It is in this context that this research was conceived. In order to respond to the multiple challenges of the $21^{\text {st }}$ century, the researchers believe that flipped classroom may be a possible answer. Flipped classroom is no different for many since foreign educators were also practicing this approach to teaching because of its effectiveness.

Since this learning approach involves a person's engagement in learning, it is but proper to analyze and determine the readiness in Mathematics flipped classroom of selected Mathematics secondary school teachers at Division Schools of Tanauan City. The researchers believe that it is best to conduct the study among Mathematics teachers as their field of specialization requires ample time for the students to gain mastery. It will also provide new insights and knowledge that they may use to blend with the demands of the $21^{\text {st }}$ century.

\subsection{Objectives of the Study}

This study determined the readiness in Mathematics flipped classroom of selected Mathematics secondary school teachers. These teachers came from different national high schools in the Division Schools of Tanauan City.

Specifically, this study sought answers to the following questions: What is the profile of the respondents in terms of sex, age, highest educational attainment; and number of seminars attended related to ICT?; How may the readiness in Mathematics flipped classroom of the respondents be described in terms of flexible environment, learning culture, intentional content; and professional educator?; Is there a significant relationship between the respondents' profile and their readiness in Mathematics flipped classroom?; and lastly, what course of action may be proposed to support the readiness of Mathematics teachers in a flipped classroom?

\section{Method}

The researchers used the descriptive correlational method of research to answer the questions posed in this endeavour. They also correlated the respondents' profile and their readiness in Mathematics flipped classroom. 
The researcher-made questionnaire was given to 41 selected secondary Mathematics school teachers at the Division Schools of Tanauan City, S.Y. 2016-2017. They were chosen as respondents since they are currently teaching Mathematics subject in their respective schools.

The study made use of a 4-point scale in which the respondents were asked to express the degree to which they agree or disagree with each of the statements by checking their appropriate choice. These are presented in terms of weighted means with their corresponding descriptive equivalents. Scale Mean Ranges Interpretation 4321 $3.51-4.002 .51-3.501 .51-2.501 .00-1.50$ Strongly Agree/Highly Ready Agree/Ready Disagree/Not Ready Strongly Disagree/Highly Not Ready. The quantitative data gathered were subjected for checking, scoring, analysis and interpretation with the help of the statistician. The researchers with the help of the statistician made a careful evaluation of the results of the questionnaires. Each item in the questionnaire was analysed and interpreted in order to arrive at definite results of the study.

\section{Results}

This chapter covers the presentation, analysis and interpretation of the quantitative data gathered in the investigation. To give an in-depth analysis and interpretation, the data are arranged thematically and sequentially resembling the presentation of specific problems posed at the beginning of the study.

\subsection{Profile of the Respondents}

The succeeding tables present the profile of the respondents in the Division Schools of Tanauan City. This was grouped according to sex, age, highest educational attainment and number of seminars attended related to ICT.

Table 1. Profile of the Respondents

\begin{tabular}{lll}
\hline \multicolumn{1}{c}{ Sex } & Frequency & Percentage \\
\hline Male & 13 & 32.00 \\
Female & 28 & 68.00 \\
Total & $\mathbf{4 1}$ & $\mathbf{1 0 0 . 0 0}$ \\
\hline \multicolumn{3}{c}{} \\
\hline Age in Years & Frequency & Percentage \\
\hline $50-59$ & 6 & 15.00 \\
$40-49$ & 16 & 39.00 \\
$30-39$ & 9 & 22.00 \\
$20-29$ & 10 & 24.00 \\
Total & $\mathbf{4 1}$ & $\mathbf{1 0 0 . 0 0}$ \\
\hline
\end{tabular}

\begin{tabular}{lll}
\hline Highest Educational Attainment & Frequency & Percentage \\
\hline Master's Degree & 6 & 15.00 \\
Bachelor's Degree with MA Units & 24 & 59.00 \\
Bachelor's Degree & 11 & 26.00 \\
Total & $\mathbf{4 1}$ & $\mathbf{1 0 0 . 0 0}$ \\
\hline
\end{tabular}

\begin{tabular}{lll}
\hline Number of Seminars Attended Related to ICT & Frequency & Percentage \\
\hline 5 and above & 9 & 22.00 \\
$3-4$ & 17 & 41.00 \\
$1-2$ & 15 & 37.00 \\
Total & $\mathbf{4 1}$ & $\mathbf{1 0 0 . 0 0}$ \\
\hline
\end{tabular}

Most of the respondents were female and belonged to the age bracket 40-49. In terms of highest educational attainment, most of them attained bachelor's degree with MA units and attended three to four seminars related to ICT.

According to Felipe (2013), it is the goal of the Department of Education to help every teacher to become not only efficient but also effective. Trainings and seminars on ICT, workshops on new methods and techniques in teaching, orientations on the K-12 Curriculum, Values Formation Seminars and the likes are being held in different parts of the country so as to prepare all the teachers in globalization. 


\subsection{Respondents Readiness in Mathematics Flipped Classroom}

The succeeding tables present the data of the respondents' readiness in Mathematics flipped classroom in terms of flexible environment, learning culture, intentional content and professional educator.

Table 2. Flexible Environment

\begin{tabular}{|c|c|c|}
\hline Item Statements & Mean & Verbal Interpretation \\
\hline As a Mathematics teacher, I can ... & & \\
\hline $\begin{array}{l}\text { 1. establish spaces and time frames that permit students to interact and } \\
\text { reflect on their learning as needed. }\end{array}$ & 3.44 & Agree \\
\hline $\begin{array}{l}2 . \quad \text { observe and monitor students continually to make appropriate } \\
\text { adjustments on their learning. }\end{array}$ & 3.56 & Strongly Agree \\
\hline $\begin{array}{l}\text { 3. rearrange learning spaces physically to accommodate a lesson or unit, } \\
\text { supporting either group work or independent study. }\end{array}$ & 3.46 & Agree \\
\hline $\begin{array}{l}\text { 4. prepare appropriate assessment systems that objectively measure } \\
\text { understanding in a way that is meaningful for students. }\end{array}$ & 3.59 & Strongly Agree \\
\hline $\begin{array}{l}\text { 5. assure that there is maximum availability of technological facilities } \\
\text { and equipment for access of students. }\end{array}$ & 3.02 & Agree \\
\hline Overall & 3.41 & Ready \\
\hline
\end{tabular}

The respondents were ready in Mathematics flipped classroom in terms of flexible environment obtaining a composite mean of 3.41. This proves that teachers nowadays tend to observe and monitor students, rearrange learning spaces and prepare appropriate assessment systems.

Table 3. Learning Culture

\begin{tabular}{|c|c|c|}
\hline Item Statements & Mean & Verbal Interpretation \\
\hline As a Mathematics teacher, I can ... & & \\
\hline $\begin{array}{l}\text { 1. scaffold the activities and make them accessible to all students } \\
\text { through differentiation and feedback. }\end{array}$ & 3.27 & Agree \\
\hline $\begin{array}{l}\text { 2. explore topics in greater depth using videos and create rich learning } \\
\text { opportunities for students where they can share their technological } \\
\text { abilities. }\end{array}$ & 3.15 & Agree \\
\hline $\begin{array}{l}\text { 3. make students actively involved in knowledge construction with the } \\
\text { help of available technology as they participate in and evaluate their } \\
\text { learning. }\end{array}$ & 3.39 & Agree \\
\hline $\begin{array}{l}\text { 4. utilize learner-centered approach inside the classroom with the } \\
\text { integration of technology-based activities. }\end{array}$ & 3.49 & Agree \\
\hline $\begin{array}{l}\text { 5. shift to delivering more learning content outside of class and using } \\
\text { class time to review, apply, and reinforce learning take work, planning, } \\
\text { and practice. }\end{array}$ & 3.46 & Agree \\
\hline Overall & 3.35 & Ready \\
\hline
\end{tabular}

The readiness level in Mathematics flipped classroom in terms of learning culture among the respondents was evidently ready which obtained a composite mean of 3.35. The flipped classroom acknowledges that everyone learns at different paces. This serves as a reason for utilizing a learn-at-your-own-pace style of education. It relies heavily on the principle that students are self-motivated (Krueger, 2014).

Table 4. Intentional Content

\begin{tabular}{lll}
\hline Item Statements & Mean & Verbal Interpretation \\
\hline As a Mathematics teacher, I can ... & & \\
$\begin{array}{l}\text { 1. prioritize concepts used in direct instruction for learners to access on } \\
\text { their own. }\end{array}$ & Agree \\
\hline
\end{tabular}


2. create relevant content (typically videos) and differentiate to make content of a lesson accessible and relevant to all students.

3. help students develop conceptual understanding as well as procedural fluency about the subject matter.

4. maximize classroom time in order to adopt student-centered methods and active learning strategies depending on the subject matter.

5. transfer more learning outside the classroom wherein the content moves from supporting role to a central role.

Overall
3.05 Agree

3.63 Strongly Agree

$3.51 \quad$ Strongly Agree

3.12 Agree

3.35 Ready

The readiness level in Mathematics flipped classroom in terms of intentional content among the respondents was ready obtaining a composite mean of 3.35. Thus, it can be inferred that the respondents are more than ready in Mathematics flipped classroom in terms of flexible environment.

Table 5. Professional Educator

\begin{tabular}{|c|c|c|}
\hline Item Statements & Mean & Verbal Interpretation \\
\hline As a Mathematics teacher, I can ... & & \\
\hline $\begin{array}{l}\text { 1. make myself available to all students for individual, small group, and } \\
\text { class feedback in real time as needed such as using skype, facebook video } \\
\text { chat, and other video conferencing applications. }\end{array}$ & 3.20 & Agree \\
\hline $\begin{array}{l}\text { 2. conduct ongoing formative assessments during class time through } \\
\text { observation and by recording data to inform future instruction. }\end{array}$ & 3.41 & Agree \\
\hline $\begin{array}{l}\text { 3. collaborate and reflect with other educators using social media and take } \\
\text { responsibility for transforming my practice in teaching. }\end{array}$ & 3.27 & Agree \\
\hline $\begin{array}{l}\text { 4. accept productive and constructive criticisms from others to enhance } \\
\text { my potentialities and capabilities in relation to my professional growth. }\end{array}$ & 3.54 & Strongly Agree \\
\hline $\begin{array}{l}\text { 5. observe students, provide relevant feedback and assess their classroom } \\
\text { work constantly. }\end{array}$ & 3.54 & Strongly Agree \\
\hline Overall & 3.39 & Ready \\
\hline
\end{tabular}

To sum it up, Mathematics teachers were ready in a flipped classroom in terms of professional educator. As revealed, it obtained a composite mean of 3.39 .

\subsection{Relationship between the Respondents' Profile and their Readiness in Mathematics Flipped Classroom}

The table shows the relationship between the respondents' profile and their readiness in Mathematics flipped classroom. The correlation of the variables was tested using the Chi-square formula.

Table 6. Relationship between the Respondents' Profile and their Readiness in Mathematics Flipped Classroom

\begin{tabular}{|c|c|c|c|c|}
\hline Variables & $\begin{array}{l}\text { Computed } \\
\chi^{2}\end{array}$ & $\begin{array}{l}\text { p } \\
\text { Value }\end{array}$ & $\begin{array}{l}\text { Decision } \\
\left(\mathbf{H}_{0}\right)\end{array}$ & Interpretation \\
\hline $\begin{array}{l}\text { Sex and Readiness in Mathematics Flipped } \\
\text { Classroom }\end{array}$ & 15.361 & 0.002 & Reject & Significant \\
\hline $\begin{array}{l}\text { Age and Readiness in Mathematics Flipped } \\
\text { Classroom }\end{array}$ & 28.802 & 0.001 & Reject & Significant \\
\hline $\begin{array}{l}\text { Highest Educational Attainment and Readiness in } \\
\text { Mathematics Flipped Classroom }\end{array}$ & 22.046 & 0.001 & Reject & Significant \\
\hline $\begin{array}{l}\text { Number of Related Seminars and Readiness in } \\
\text { Mathematics Flipped Classroom }\end{array}$ & 19.807 & 0.003 & Reject & Significant \\
\hline
\end{tabular}

The table shows that when the profile of the respondents in terms of sex was correlated to their readiness in Mathematics flipped classroom, the computed Chi-square value is 15.361. Acquiring the equivalent p-value of 0.002 , the null hypothesis was rejected. This means that there is a significant relationship between the profile of the respondents in terms of sex and their readiness in Mathematics flipped classroom. 
The second variable correlated with readiness in Mathematics flipped classroom was the respondents' age. The computed Chi-square value was 28.802 with its equivalent $p$-value of 0.001 . Since $p$-value is less than 0.05 , the null hypothesis was rejected. This means that there is a significant relationship between the respondents' profile in terms of age and their readiness in Mathematics flipped classroom.

The third variable correlated with readiness in Mathematics flipped classroom was the respondents' highest educational attainment. Obtaining a computed Chi-square value of 22.046 and p-value of 0.001 which is less than 0.05 , the null hypothesis was rejected. This means that there is a significant relationship between the respondents' profile in terms of highest educational attainment and their readiness in Mathematics flipped classroom.

The fourth variable correlated with readiness in Mathematics flipped classroom was the respondents' number of seminars attended related to ICT. Acquiring a computed Chi-square value of 19.807 and p-value of 0.003 which is less than 0.05 , the null hypothesis was rejected. This means that there is a significant relationship between the respondents' profile in terms of number of seminars attended related in ICT and their readiness in Mathematics flipped classroom.

\subsection{Course of Action to Support the Readiness of Mathematics Teachers in a Flipped Classroom}

Table 7. Course of Action to Support the Readiness of Mathematics Teachers in a Flipped Classroom

\begin{tabular}{|c|c|c|c|c|}
\hline Objectives & Strategies & $\begin{array}{l}\text { Persons } \\
\text { Involved }\end{array}$ & $\begin{array}{l}\text { Target } \\
\text { Date }\end{array}$ & Expected Output \\
\hline $\begin{array}{l}\text { 1. To orient and practice } \\
\text { teachers on technology } \\
\text { integration in instruction, allow } \\
\text { oneself in experimenting with } \\
\text { technology tools }\end{array}$ & $\begin{array}{l}\text { Learning management system } \\
\text { may be used to distribute } \\
\text { materials, track students' } \\
\text { progress and allow students } \\
\text { to ask questions. }\end{array}$ & $\begin{array}{l}\text { School } \\
\text { Officials } \\
\text { and } \\
\text { Faculty }\end{array}$ & $\begin{array}{l}\text { SY } 2017- \\
2018\end{array}$ & $\begin{array}{l}\text { Teachers and other school officials will } \\
\text { be more knowledgeable, aware and } \\
\text { prepared on technology integration in } \\
\text { teaching using flipped classroom } \\
\text { approach to meet the challenging } \\
\text { demands of the } 21^{\text {st }} \text { century. }\end{array}$ \\
\hline $\begin{array}{l}\text { 2. To enhance collaborative } \\
\text { instruction among Mathematics } \\
\text { teachers through co-teaching } \\
\text { and team teaching, buddy up } \\
\text { with one or more teaching } \\
\text { partners }\end{array}$ & $\begin{array}{l}\text { Teaching partners may help } \\
\text { in recording lessons and may } \\
\text { serve as a sounding board for } \\
\text { ideas. }\end{array}$ & $\begin{array}{l}\text { Principal } \\
\text { and } \\
\text { Faculty }\end{array}$ & $\begin{array}{l}\text { SY } 2017- \\
2018\end{array}$ & $\begin{array}{l}\text { Faculty members who are well- } \\
\text { equipped with knowledge on } \\
\text { mathematics flipped classroom. }\end{array}$ \\
\hline $\begin{array}{l}\text { 3. To expose teachers to } \\
\text { innovation in technology such } \\
\text { as videos and podcasts }\end{array}$ & $\begin{array}{l}\text { Flip a few lessons and build } \\
\text { up until you've flipped one } \\
\text { entire class. Then use lessons } \\
\text { learned to flip other classes. }\end{array}$ & $\begin{array}{l}\text { School } \\
\text { Officials } \\
\text { Faculty }\end{array}$ & $\begin{array}{l}\text { SY } 2017- \\
2018\end{array}$ & $\begin{array}{l}\text { Teachers will be skilled and well- } \\
\text { equipped in using technology as } \\
\text { instructional material and will be more } \\
\text { creative, resourceful and innovative. }\end{array}$ \\
\hline $\begin{array}{l}\text { 4.To organize small student } \\
\text { groups that serve as ongoing } \\
\text { work groups for in-class } \\
\text { activities. }\end{array}$ & $\begin{array}{l}\text { The idea facilitates learning } \\
\text { and gives students a preview } \\
\text { of real world work, where } \\
\text { group problem solving and } \\
\text { project-based learning are } \\
\text { routine. }\end{array}$ & $\begin{array}{l}\text { Faculty } \\
\text { and } \\
\text { Students }\end{array}$ & $\begin{array}{l}\text { SY } 2017- \\
2018\end{array}$ & $\begin{array}{l}\text { Students who are independent learners } \\
\text { and problem solvers. }\end{array}$ \\
\hline
\end{tabular}

\section{Discussion}

According to Bantugan (2009), teachers are potent factors in education. They are responsible for shaping the youth through quality education. With this context, it is imperative for teachers to acquire the totality of information and qualities of education through instructions and training which maximize the development of an individual physically, mentally, and morally. Teaching strategies acquired from seminars and workshops can be effective in changing the lives of students.

Hill (2012) added that in order to become a truly great teacher, one must go beyond the textbook and attend workshops and ongoing education courses to truly master the practice. There are conferences, workshops, and continuing education that could give the teacher extra help in technology for their students. There are also workshops on how to integrate technology into the classroom and how to make it cross curricular. These conferences and workshops will give the teacher the information and tools needed to integrate technology in the classroom. 
The above contexts proved that attending related seminars may affect the readiness of teachers in a mathematics flipped classroom since they develop knowledge and understanding on technological concepts and they acquire skills that are necessary to reinforce the teaching approach.

\section{References}

Ackerman, B., \& Spradlin, K. (2010). The effectiveness of computer-assisted instruction in developmental mathematics. Liberty University. Lynchburg, VA.

Atkinson. et al. (2011). Podcasting in education: Student attitudes, behavior and self-efficacy. Journal of Educational Technology \& Society, 14(2), 236-247.

Badri, M., Mohaidat, J., \& Rashedi, A. (2013). Technology readiness of school teachers - An empirical study of measurement and segmentation. Journal of Information Technology Education: Research, 13, 257-275. https://doi.org/10.4172/2169-0316.1000117

Bantugan, M. (2009). The importance of trainings and seminar-workshops to teachers' improvement. Bagac Elementary School. Bataan, Philippines. Retrieved from http://www.mybataan.com/content/view/367/96

Baron, $\mathrm{R}$ (2007). Effective criticism made easy: Basic rules for delivering negative feedback to others. $R \& D$ Innovator, 1(3). Retrieved from http://www.winstonbrill.com/bril001/html/article_index/articles/150/article9_body.html

Bell, M. (2015). An investigation of the impact of a flipped classroom instructional approach on high school students. Content Knowledge and Attitudes Toward the Learning Environment. Retrieved from http://scholarsarchive.byu.edu/etd

Bishop, J. L., \& Verleger, M. A. (2013). The flipped classroom: A survey of the research. In ASEE National Conference Proceedings. Atlanta, GA. Retrieved http://faculty.up.edu/vandegri/FacDev/Papers/Research_flipped_classroom.pdf

Boom, C. \& Thomas, M. (2012). Six reasons why criticism is a good thing. Guardian Culture Professionals Network. Retrieved from http://www.theguardian.com/culture-professionals-network/culture-professionalsblog/2012/feb/09/reasons-tips-criticism-arts

Cacciamani, S., et al. (2011). Influence of participation, facilitator styles and metacognitive reflection on knowledge building in online university courses. Computers \& Education, 58(3), 874-884. Retrieved From http://www.sciencedirect.com/science/article/pii/S0360131511002636

Caranto, L., David, J., \& Mendoza, G. (2015). Effectiveness of video presentation to students' learning. International Journal of Nursing Science, 5(2), 81-86. https://doi.org/10.5923/j.nursing.20150502.07

Clark, D. (2007). 10 reasons to dump lectures. Retrieved from http://donaldclarkplanb.pot.ca/2007/12/10reasonsto-dump-lectures.html/

Common Core Standards in Mathematics. (2014). Conceptual Understanding in Mathematics. Wiggins, G.

Creswell, J. (2008). Educational research: Planning, conducting, and evaluating quantitative and qualitative research. Third Edition. Pearson Prentice Hall, USA.

Felipe, R. (2013). The importance of trainings and seminar-workshops to teachers improvement. Teachers for Teachers. Retrieved from http://www.teachersessay.com/the-importance-of-seminars-and-trainings-inimproving-teachers-performance/

Filardo, M. (2008). Good buildings, better schools: An economic stimulus opportunity with long-term benefits. Retrieved from http://www.sharedprosperity.org/bp216/bp216.pdf

Fisher, G. (2015). Study: Girls do better in school when taught by women. Retrieved from https://qz.com/466246/study-girls-do-better-in-school-when-taught-by-women/

Flipped Learning Network. (2014). Flipped learning network unveils formal definition of flipped learning. Retrieved from http://www.flippedlearning.org/domain/46

Fulton, K. (2012). 10 reasons to flip. Phi Delta Kappan, 94(2), 20-24. Retrieved from https://doi.org/10.1177/003172171209400205

Gojak, L. (2012). To flip or not to flip: That is not the question! National Council of Teachers of Mathematics. Retrieved From http://www.nctm.org/about/content.aspx?id=34585

Hamdan, N., et al. (2013). A Review of Flipped Learning. Pearson - Research \& Innovation Network. Retrieved 
from http://researchnetwork.pearson.com/wpcontent/uploads/LitReview_flippedLearning1.pdf

Hanover Research. (2013). Best practices for the flipped classroom. Retrieved from http://www.hanoverresearch.com/2013/10/bestpractices-for-the-flipped-classroom/

Hennick, C. (2014). Flipped your classroom. Scholastic. Retrieved from http://proxygsuarml.galileousg.edu/login?url=http://search.proquest.com/docview/1613618815? accountid $=8366$

Hill, L. (2012). The value of workshops and continuing education for teachers. The evoLLLution. Oakdale Christian Academy. Retrieved from https://evolllution.com/opinions/the-value-of-workshops-andcontinuing-education-for-teachers/

Horn, M., \& Staker, H. (2012). Classifying K-12 blended learning. San Mateo: Innosight Institute, Inc. Retrieved from http://www.innosightinstitute.org/innosight/wpcontent/uploads/2012/05/classifying-K-12-blendedlearning2.pdf

Kim, M., Kim, S., Khera, O., \& Getman, J. (2014). The experience of three flipped classrooms in an urban university: An exploration of design principles. The Internet and Higher Education, 22, 37-50. https://doi.org/10.1016/j.iheduc.2014.04.003

Krueger, J. (2014). Five reasons against the flipped classroom. Project Based Learning. Retrieved from https://stratostar.net/five-reasons-against-the-flipped-classroom/

Kybartaite, A. (2010). Impact of modern educational technologies on learning outcomes. Application for eLearning in Biomedical Engineering. Retrieved from http://evicab.aalto.fi/outcomes/kybartai/thesis.pdf

Lambert, C. (2013). Twilight of the lecture. Harvard Magazine, pp. 23-27.

Leicht, R., Litzinger, T., Messner, J., \& Zappe, S. (2009). Employing the classroom flip to move lecture out of the classroom. Journal of Applications and Practices in Engineering Education, 3(1), 19-31.

Limon, M. R. (2016). The effect of the adequacy of school facilities on students' performance and achievement in technology and livelihood education. International Journal of Academic Research in progressive Education and Development, 5(1). Mariano Marcos State University. Ilocos Norte, Philippines. https://doi.org/10.6007/IJARPED/v5-i1/2058

Marlowe, C. (2012). The effect of the flipped classroom on student achievement and stress. Retrieved from http://scholarworks.montana.edu/xmlui/bitstream/handle/1/1790/MarloweC0812.pdf?sequence=1

Mazur, E. (2009). Farewell, lecture? Science, 323(5910), 50-51. Retrieved from https://doi.org/10.1126/science.1168927

Morgan, H. (2014). Focus on technology: Flip your classroom to increase academic achievement. Childhood Education, 90(3), 239-241. https://doi.org/10.1080/00094056.2014.912076

Nehr, J. (2009). The impact of online learning on the middle school student. Retrieved from http://minds.wisconsin.edu/bitstream/handle/1793/43279/2009nehrj.pdf?source=1<

Ogochukwu, N. (2010). Enhancing students interest in mathematics via multimedia presentation. African Journal of Mathematics and Computer Science Research, 3(7), 107-113.

Overmyer, J. (2012). Flipped classroom 101. Principal, 46-47. Retrieved from http://www.naesp.org

Parasuraman, A. (2008). The effects of the dimensions of technology readiness on technology acceptance: An empirical analysis. J. Int. Mark, 22, 19-39. https://doi.org/10.1002/dir.20119

Patel, P. (2013). An experiment in flipping: Lack of time for hands-on learning prompted a classroom flip, 1-4. Retrieved from http://www.amle.org/browseby/topic/whatsnew/wndet/TabId?270/a

Reddy, S., Roehl, A., \& Shannon, G. (2013). The flipped classroom: An opportunity to engage millennial students through active learning. Journal of Family and Consumer Sciences, 105(2), 44-49. https://doi.org/10.14307/JFCS105.2.12

Sainani, K. (2013). Flipped classroom overview. Flipped Classroom Field Guide. Retrieved from https://docs.google.com/document/d/1QhlSmNkp9D7Por0T27XjnL2OedqJGtxov Ohn4juDWVY/pub

Schneider, M. (2002). Do school facilities affect academic outcomes? Washington, DC: National Clearinghouse for Educational Facilities. Retrieved from http://www.edfacilities.org/pubs/outcomes.pdf

Seaboyer, J. (2013). The role of technology-assisted assessment in fostering critical reading in undergraduate 
literary studies. International Computer Assisted Assessment Conference. Southampton, UK.

Siegle, D. (2014). Technology: Differentiating instruction by flipping the classroom. Gifted Child Today, 37(1), 51-55. https://doi.org/10.1177/1076217513497579

Strohmyer, D. (2016). Student perceptions of flipped learning in a high school math classroom. Retrieved from $\mathrm{http} / / /$ scholarworks.maldenu.edu/cgi/viewcontent.cgi?article $=3281 \&$ context $=$ dissertations

Teaching \& Educational Development Institute. (2012). Case Study: Dr. Judith Seaboyer. The University of Queensland, Australia. Retrieved from http://www.uq.edu.au/tediteach/flipped-classroom/docs/csseaboyer.pdf

Tetreault, P. (2013). The flipped classroom: Cultivating student engagement. Retrieved from https://dspace.library.uvic.ca/bitstream/handle/1828/5086/Tetreault_Patricia_MEd_2013.pdf? sequence=1

The Policy Matters. (2017). Ideas into action. Center for Study of Social Policy. Retrieved from http://www.cssp.org/policy/policy-matters

Ukueze, A. (2007). Learner variable of academic performance and adjustment of junior secondary student. The Counsellor, 23(2), 172-183.

Wiggins, G. (2014). Conceptual understanding in Mathematics. General. Retrieved from https:/grantwiggins.wordpress.com/2014/04/23/conceptual-understanding-in-mathematics/

\section{Copyrights}

Copyright for this article is retained by the author(s), with first publication rights granted to the journal.

This is an open-access article distributed under the terms and conditions of the Creative Commons Attribution license (http://creativecommons.org/licenses/by/4.0/). 